\title{
Implementasi Platform Media Sosial Sebagai Business Support oleh Pelaku Usaha Wisata di Kota Batam
}

\author{
Saut Pintubipar Saragih \\ Sistem Informasi, Universitas Putera Batam \\ pipin.sitio@gmail.com
}

\begin{tabular}{l} 
Article Info \\
\hline Article history: \\
Received : 15-11-2018 \\
Revised : 27-11-2018 \\
Accepted : 04-12-2018 \\
\hline
\end{tabular}

Keyword:

Social Media,

Internet,

Pariwisata

\begin{abstract}
Batam City is a marine island which surrounded by shoes and baetiful marine tourism spots. Growth and existence of social media platform in the era of information technology particularly in tourism industry is very helpful either profitable for the perpetrators of the tourism industry because social media can be used for an effective and efficient in the information sharing to all tourists or potential visitors. In this research the objects will be examined is how the industry of tourism business entrepreneurs, operators or managers implement these social media platforms at supporting their business processes in order to get result in increasing tourist visits, increasing tourism objects and company popularity and eventually increasing the economic income consistently. In this research respondent that participated in this study were spread in 4 sub-districts, namely Galang sub-district, Bulang sub-district, Nongsa sub-district and Sekupang subdistrict. There are several social media platforms used by the tourism industry entrepreneurs in Batam, they are Facebook, Instagram, Youtube, Whatsapp group, Line, Twitter and Linkedin. The platforms that $100 \%$ used by the entrepreneurs is facebook platforms which means all respondents are using this platform and followed by the Instagram consecutively. The type of account used by the marine tourism industry didn't use a business account but some of them uses a regular account. Based on the results of the research data test, it was concluded that there were influences obtained by the marine tourism industry in Batam city in improving business, corporate profits and also increasing tourist visits through travel agencies provided or increased direct visits to managed tourism objects.
\end{abstract}

Copyright (C) 2018 Journal of Applied Informatics and Computing. All rights reserved.

\section{Pendahuluan}

Media digital sebagai sebuah sumber informasi dan platform untuk berkomunikasi yang digunakan para turis berkembang dengan sangat signifikan [1]. Digital media merupakan sebuah produk dan jasa yang berawal dari media, hiburan, industri informasi dan sub-sektor yang ada dibawahnya. Sub-sektor tersebut antara lain adalah digital platform, digital content, dan services (pelayanan). Pada dasarnya ketiga hal itu ditampilkan dalam digital platform. Media sosial merupakan sebuah implementasi dari digital platform yang mencoba memfasilitasi pelayanan dengan memaksimalkan konten digital [2]. Di Indonesia pertumbuhan digital juga sangat signifikan. Pada tahun 2015 Indonesia mengalami pertumbuhann sebesar 14 persen dari tahun 2014. Sebagai sebuah perbandingan kecil bahwa pengguna internet di Indonesia pada tahun 2015 adalah 72,7 juta pengguna dengan 95 persen diantaranya adalah pengguna media sosial [3].

Pemanfaatan media sosial sebagai alat strategis sudah banyak dilakukan oleh pelaku industri wisata termasuk para penyedia layanan dan jasa untuk wisatawan [4]. Pemanfaatan utama media sosial digunakan sebagai sebuah fasilitas berkomunikasi yang sangat cepat dan efisien [5]. Salah satu contoh penggunaan media sosial untuk pariwisata adalah aplikasi facebook pada tahun 2012 telah menunjukkan bahwa $76 \%$ wisatawan memposting foto liburan di jejaring sosial [6]. Penggunaan media sosial merupakan alat yang sangat bagus didalam pengembangan jaringan sosial termasuk didalam industri wisata pada era teknologi informasi saat ini dimana hal ini juga sering dikaitkan hubungannya dengan bidang yang lain termasuk sosial dan ekonomi pada dunia nyata [7] 
Di Indonesia pertumbuhan pengguna media sosial pada tahun 2016 adalah 27 juta pengguna baru [8]. Sebuah pengamatan mengatakan bahwa 90 persen perusahaan menggunakan social networks untuk melakukan strategi bisnisnya yakni strategi marketing [9]. Sumbangan pariwisata pada bidang ekonomi sangat tinggi. Pada 2016 pariwisata menyumbang pdb sebesar 9,8 persen dari total produk domestic bruto senilai 7.420,5 miliar [10]. Perkembangan industri pariwisata di Indonesia bisa dikatakan bertumbuh dengan sangat baik. Berdasarkan data terakhir yang dikeluarkan oleh badan pusat statistika Indonesia (BPS) bahwa jumlah kunjungan wisatawan mancanegara atau wisman ke Indonesia pada april 2017 naik 26,75 persen 1,14 juta kunjungan [11].

Kota Batam yang menjadi pintu masuk wisatawan di Kepulauan Riau menjadi adalah kota terdekat ke negara Singapura, Malaysia, Fillipina, Vietnam, dan Thailand mengalami penurunan sebesar 5,49 persen walaupun masih pada urutan nomor empat (4) dari total 19 pintu masuk utama wisman di Indonesia selama tahun 2017 [11]. Namun Secara khusus kota Batam berdasarkan jumlah kunjungan selama tiga tahun terhitung dari 2014 sampai 2016 mengalami penurunan secara konsisten. Pada 2014 jumlah kunjungan wisatawan mancanegara adalah 171.907 pengunjung, 2015170.081 dan terakhir 2016 menurun kembali dengan jumlah 159.277 pengunjung wisatawan mancanegara [11]. Menurut satuan kerja daerah yang dibawahi oleh Koridor Pariwisata daerah (KPD) Batam merupakan tujuan wisata untuk Wisata Kota, Wisata Bahari dan Wisata MICE (Meeting, Incentive, Convention and Exhibition), Wisata Minat Khusus, Wisata Terpadu, Eksklusif, Wisata Agro dan Wisata Alam [12].

\begin{tabular}{|c|c|c|c|c|c|c|c|c|}
\hline \multirow{2}{*}{ Pintu Masuk } & \multicolumn{5}{|c|}{ Jumlah Kunjungan } & \multirow{2}{*}{$\begin{array}{l}\text { Perubahan } \\
\text { Apr } 2017 \\
\text { thd 2016 } \\
(\%) / 6\end{array}$} & \multirow{2}{*}{$\begin{array}{l}\text { Perubahan } \\
\text { Apr } 2017 \\
\text { tha Mar } \\
2017(\%)\end{array}$} & \multirow{2}{*}{$\begin{array}{l}\text { Perubahan } \\
\text { Jan-Apr } \\
2019 \text { th } \\
2016 \text { (\%) } \\
\end{array}$} \\
\hline & $\begin{array}{l}\text { Apr } \\
2016 \\
\end{array}$ & $\begin{array}{l}\text { Mar } \\
2017\end{array}$ & $\begin{array}{c}\text { App } \\
2017 "\end{array}$ & $\begin{array}{c}\text { Jan-Apr } \\
2016\end{array}$ & $\begin{array}{l}\text { Jann-Apr } \\
2017\end{array}$ & & & \\
\hline (1) & (2) & (3) & (4) & (5) & (6) & (7) & (8) & (9) \\
\hline \multicolumn{9}{|l|}{ L. Wisman melaui 19 Pintu Utama } \\
\hline A. Wisman Reguler & 811233 & 909182 & 966936 & 3083526 & 3617779 & 19,19 & 6,35 & 17,33 \\
\hline 1. Soelamo-Hata & 188359 & 215651 & 211131 & 708858 & 800001 & 12,08 & $.2,10$ & 1286 \\
\hline 2. Ngurah Rai & 367370 & 422757 & 474610 & 1432835 & 1797789 & 29,19 & 12,27 & 25,47 \\
\hline 3. Kuaknamu & 13280 & 20578 & 18225 & 53941 & 71943 & 37,76 & . $-1,09$ & 33,37 \\
\hline 4. Batam & 125573 & 127308 & 134218 & 480136 & 486315 & 6,88 & 5,43 & 1,29 \\
\hline 5. Sam Ratuang & 1427 & 5148 & 5899 & 4884 & 23832 & 312,82 & 14,43 & 387,96 \\
\hline 6. Juanda & 18186 & 17019 & 20112 & 62709 & 66291 & 10,54 & 18,12 & 5,71 \\
\hline 1. Enilong & 1426 & 2626 & 1669 & 6720 & 8348 & 18,44 & $.35,68$ & 24,23 \\
\hline 8. Ad Sumamo & 548 & 775 & 669 & 2260 & 2028 & 20,26 & $-14,97$ & $-10,27$ \\
\hline 9. Mranglabau & 4063 & 4989 & 4558 & 15761 & 17612 & 12,18 & 8,64 & 11,74 \\
\hline 10. Taning Priok & 4897 & 4871 & 4943 & 22180 & 18380 & 0,94 & 1,48 & $-17,13$ \\
\hline 11. Tanjung Pinarg & 8042 & 7810 & 9113 & 31076 & 33927 & 13,69 & 17,07 & 9,17 \\
\hline 12. Bandara ht: Lombook & 5407 & 11823 & 12224 & 24109 & 42479 & 127,19 & 3,90 & 76,20 \\
\hline 13. Hasanudin & 1056 & 1502 & 1149 & 3867 & 5573 & 8,81 & $.23,50$ & 44,12 \\
\hline 14. Sepringan & 555 & 402 & 356 & 3075 & 1489 & $.35,86$ & . 11,44 & $.51,58$ \\
\hline 15. Sutitan Yyarif fasim II & 1786 & 3405 & 3256 & 7311 & 12367 & 82,31 & 4,38 & 69,16 \\
\hline 16. Adi Sucpito & 7223 & 12389 & 12887 & 28342 & 43936 & 78,42 & 4,02 & 55,02 \\
\hline 17. Husen Sastrangagala & 30806 & 17568 & 15856 & 66000 & 55694 & 48,53 & 9,74 & $-16,52$ \\
\hline 18. Taningu Uban & 23018 & 25198 & 28158 & 97721 & 101555 & 22,33 & 11,75 & 3,92 \\
\hline 19. Tanung Balaikarmun & 8201 & 7363 & 7751 & 31741 & 28820 & $.5,49$ & 5,27 & 9,20 \\
\hline $\begin{array}{l}\text { B. Wisman Khususus (wisman } \\
\text { lansia, rohaniawan, diklat, } \\
\text { riset, dll) }\end{array}$ & 23628 & 24474 & 271.4 & 133602 & 106632 & 15,09 & 11,11 & $-20,19$ \\
\hline Sub Jumlah 19 Pintu $(A+B)$ & 834861 & 933656 & 994130 & 3217128 & 3724411 & 19,08 & 6,48 & 15,77 \\
\hline
\end{tabular}

Gambar 1. Kunjungan Wisatawan Mancanegara ke kota Batam 2017 (Sumber: badan pusat statistic 2017).

\section{TINJAUAN PUSTAKA}

\section{A. Media Sosial}

Integrasi teknologi informasi terutama internet dan kehidupan sosial menjadi sebuah era digital yang tidak bisa dikesampingkan pada saat ini. Menurut Boyd dan Ellison (2008) Salah satu perkembangan signifikan dalam evolusi Internet adalah meningkatnya platform media sosial yang memungkinkan pengguna internet berkolaborasi, mengkomunikasikan dan mempublikasikan konten asli seperti blog, video, wiki, ulasan, atau foto [4]. Media sosial mengacu pada sarana interaksi di antara orang-orang dimana mereka menciptakan, berbagi, dan bertukar informasi dan gagasan di komunitas dan jaringan maya. Andreas Kaplan dan Michael Haenlein (2010) mendefinisikan media sosial sebagai sekelompok aplikasi berbasis internet yang dibangun di atas dasar ideologi dan teknologi Web 2.0 dan yang memungkinkan penciptaan dan pertukaran konten buatan pengguna [13]. Menurut Ahlqvist (2008) Media sosial berinteraksi dengan platform yang digunakan pengguna Untuk menciptakan, berbagi, dan bertukar informasi konten melalui komunitas dan teknologi Web 2.0 [14]

Menurut Toivonen (2007) definisi fungsional media sosial mengacu pada interaksi orang dan juga untuk menciptakan, berbagi, bertukar dan mengomentari konten komunitas virtual dan jaringan [15]. Platform media sosial menurut Camarero (2011) bahwa media sosial menyediakan cara tak terbatas bagi konsumen untuk berinteraksi, mengungkapkan, berbagi, dan membuat konten tentang merek dan produk. Menurut Kaplan dan Haenlein (2010) bahwa media sosial memungkinkan pengelola destinasi untuk berinteraksi dengan pengunjung dengan biaya yang relatif rendah dan tingkat efisiensi yang lebih tinggi yang dapat dicapai dengan alat komunikasi tradisional [16].

Saat ini media sosial telah bertransformasi menjadi sebuah sarana efektif bagi perusahaan dalam membangun komunikasi dengan seluruh pelanggan. Hal tersebut disebabkan karena kecepatan informasi yang sampai kepada pelanggan yang hampir tidak tertandingi karena seluruh pengguna bias terhubung dengan pemilik usaha atau pengelola perusahaan. Berbeda dengan media tradisional yang sifatnya komunikasi satu arah seperti surat kbar cetak, televise maupun radio dalam penyajian informasi, berita dan hiburan. Media sosial memungkinkan setiap orang untuk menjadi pencipta dan membagikannya melalui komunikasi interaktif dua arah.

Media sosial memainkan peran penting baik pada permintaan maupun pada sisi penawaran pariwisata yang memungkinkan destinasi untuk berinteraksi langsung dengan pengunjung melalui berbagai platform internet dan memantau dan bereaksi terhadap pendapat dan evaluasi pengunjung terhadap layanan. Media baru dalam komunikasi memberikan pendekatan pemasaran yang lebih murah untuk destinasi dan menawarkan banyak kesempatan bagi keterlibatan pengunjung dalam menarik calon pengunjung ke destinasi. Media sosial sebagai alat pemasaran pariwisata 
semakin meyakinkan pemasar destinasi sehingga menjadi bagian integral dari kampanye pemasaran [17].

Peran media sosial dalam pariwisata semakin diperhatikan dan diteliti sebagai topik yang sedang berkembang. Media sosial memainkan peran yang semakin penting dalam banyak aspek pariwisata, terutama dalam pencarian informasi dan perilaku pengambilan keputusan dan promosi pariwisata yang berfokus pada praktik terbaik untuk berinteraksi dengan konsumen melalui saluran media sosial (pembagian liburan sosial Pengalaman). Memanfaatkan media sosial untuk memasarkan produk wisata telah terbukti menjadi strategi yang sangat baik. Banyak negara menganggap media sosial sebagai alat penting untuk mempromosikan industri pariwisata mereka [7]. Banyak ketidaksetujuan terhadap pengelompokan jenis media sosial diantara para peneliti dan ilmuwan. Tetapi terdapat enam jenis media sosial yang telah diidentifikasi yaitu diantaranya situs jejaring sosial, blog atau komunitas konten, proyek kolaboratif, virtual dunia sosial, dan dunia game maya. Namun, ada jenis media sosial lainnya seperti microblog, ulasan konsumen \& situs web rating, dan fora internet. Namun begitu jumlah media sosial yang berubah-ubah peran sosial media yang paling penting adalah mendorong pengguna dan pelancong untuk memposting dan berbagi pengalaman perjalanan, komentar dan pendapat mereka, dengan menjadikannya sebagai sumber informasi bagi pengguna lain [6]

\section{B. Media Sosial Pada Pariwisata}

Menurut KBBI, Pariwisata ialah suatu kegiatan yang berhubungan dengan perjalanan rekreasi, turisme atau pelancongan. Kemudian menurut sumber Wikipedia, Pariwisata (turisme) ialah suatu perjalanan yang dilakukan untuk rekreasi atau liburan. Di Indonesia pada UU No. 10 Tahun 2009, Pariwisata ialah berbagai macam kegiatan wisata dan didukung berbagai fasilitas serta layanan yang disediakan oleh masyarakat, pengusaha, pemerintah dan pemerintah daerah. Sedangkan menurut World Tourism Organization (WTO), Pariwisata merupakan suatu kegiatan manusia yang melakukan perjalanan ke dan tinggal di daerah tujuan di luar lingkungan kesehariannya. Berdasarkan pengertian yang telah disebutkan dapat disimpulkan bahwa pariwisata merupakan sebuah kegiatan yang cenderung melakukan perjalanan dan kunjungan kedaerah yang berbeda dengan tujuan untuk mendapatkan hiburan dan rekreasi.

Pada era informasi saat ini pariwisata sudah berevolusi seiring dengan munculnya teknologi internet. Didukung dengan pembangunan infrastruktur yang memadai untuk memungkinkan melakukan pencarian informasi secara cepat dan efisien yang mana salah satu cara yang digunakan adalah dengan menggunakan media social [9]. Media sosial pada pariwisata merupakan alat penting untuk melakukan analisis sikap wisatawan tentang pengalaman mereka dan hal ini diperkuat oleh peningkatan pembelian dan rekomendasi kepada pengguna lain berdasarkan pengalaman yang sudah dialami sebelumnya pada tujuan wisata yang tlah dikunjungi. Wisatawan perlu tahu melalui sumber terpercaya bagaimana pengalaman mereka yang mengurangi ketidakpastian akan destinasi yang akan dikunjungi dan menciptakan harapan pelayanan dan pada akhirnya akan menemukan hal yang diharapkan di tempat tujuan wisata yang dikunjungi [6].

\section{Manfaat Media Sosial Dalam Industri Pariwisata}

Beberapa manfaat yang dapat diambil dengan menggunakan media sosial adalah sebagai berikut:

a) Menurut Safko (2009) Dari sudut pandang bisnis, inti dari media sosial adalah tentang memungkinkan pembicaraan. Media sosial juga tentang cara pembicaraan ini bisa dihasilkan, dipromosikan, dan dijadikan pendapatan [18].

b) Berdasarkan hasil penelitian yang dilakukan oleh Gumilar (2015) bahwa media sosial berguna untuk sarana promosi pengelolaan proses bisnis dan sarana untuk memperbaharui informasi tentang produk [3].

c) Memanfaatkan Media sosial untuk membangun hubungan dengan pelanggan, menumbuhkan dan mendapatkan kepercayaan diri dari pelanggan [9].

d) Sosial media digunakan untuk berbagi pengetahuan, Sebagai fasilitas aksesibilitas untuk menjangkau informasi, membangun jaringan sosial, menyoroti aksesibilitas layanan pariwisata dan memberi wawasan [19].

Sosial media juga dimanfaatkan untuk Menciptakan serta meningkatkan kesadaran akan tujuan wisata, Meraih publisitas global, Mendorong pengunjung untuk merencanakan rencana mereka perjalanan, Memperkuat citra tujuan sebagai tujuan favorit, Menargetkan pasar baru / spesifik, Meningkatnya jumlah pengunjung, Menciptakan keistimewaan di sekitar tujuan, Meningkatkan jumlah email pelanggan, Meningkatkan jumlah basis penggemar Facebook, Mengubah posisi tujuan di dalam pikiran Pengunjung, Mengembalikan tujuan sebagai favorit bagi pengunjung [17]

\section{Strategi dan Dukungan Pariwisata Oleh Pemerintah}

Strategi dan Dukungan Pariwisata Oleh Pemerintah

Berdasarkan Peraturan pemerintah Republik Indonesia Nomor 50 Tahun 2011 tentang Tentang Rencana Induk Pembangunan Kepariwisataan Nasional Tahun 2010-2025 terutama pada Bab 1 Ketentuan umum pasal 1 Dalam Peraturan Pemerintah ini yang dimaksud dengan [20]:

1. Pasal 1. Kepariwisataan adalah keseluruhan kegiatan yang terkait dengan pariwisata dan bersifat multidimensi serta multidisiplin yang muncul sebagai wujud kebutuhan setiap orang dan negara serta interaksi antara wisatawan dan masyarakat setempat, sesame wisatawan, Pemerintah, Pemerintah Daerah, dan pengusaha.

2. Pasal 8. Daya Tarik Wisata adalah segala sesuatu yang memiliki keunikan, keindahan, dan nilai yang berupa keanekaragaman kekayaan alam, budaya, dan hasil 
buatan manusia yang menjadi sasaran atau tujuan kunjungan wisatawan.

3. Pasal 9. Aksesibilitas Pariwisata adalah semua jenis sarana dan prasarana transportasi yang mendukung pergerakan wisatawan dari wilayah asal wisatawan ke destinasi pariwisata maupun pergerakan di dalam wilayah Destinasi Pariwisata dalam kaitan dengan motivasi kunjungan wisata.

4. Pasal 14. Pemasaran Pariwisata adalah serangkaian proses untuk menciptakan, mengkomunikasikan, menyampaikan produk wisata dan mengelola relasi dengan wisatawan untuk mengembangkan Kepariwisataan dan seluruh pemangku kepentingannya.

5. Pasal 15. Industri Pariwisata adalah kumpulan Usaha Pariwisata yang saling terkait dalam rangka menghasilkan barang dan/atau jasa bagi pemenuhan kebutuhan wisatawan dalam penyelenggaraan pariwisata. Berdasarkan peraturan pemerintah yang tersebut dapat dikatakan bahwa industri pariwisata merupakan sebuah sektor yang sangat penting bagi pemerintah untuk mendukung peningkatan perekonomian nasional maupun perekonomian rakyat di daerah. Pada pasal yang disebutkan bahwa kesuksesan industri pariwisata dapat didukung oleh adanya daya tarik, aksesibilitas dan prasarana umum yang ada dan hal tersebut dapat di informasikan terhadap pengunjung atau wisatawan melalui media sosial sebagai isi konten yang akan dibagikan didalam sosial media

\section{METODOLOGI PENELITIAN}

\section{A. Kerangka Pemikiran Penelitian}

Pengguna Media sosial yang semakin banyak dan bertambah dengan cepat bahkan seluruh pengguna internet sebanyak 95 persen mengakses media sosial menjadikan media sosial sangat bermanfaat untuk menyampaikan informasi dalam bentuk digital, menumbuhkan hubungan dengan para pelanggan, membangun sebuah komunikasi dua arah, membangun kepercayaan diri pelanggan terhadap produk dan juga membangun popularitas. Industri pariwisata di kota Batam yang mengalami penurunan saat ini menjadi bukti bahwa pemanfaatan teknologi informasi seperti media sosial masih belum maksimal pemanfaatannya. Keberadaan media sosial didalam meningkatkan kunjungan wisatawan ke objek tujuan wisata dapat ditingkatkan melalui menyampaikan informasi, menigkatkan kunjungan, membangun popularitas dan meningkatkan pendapatan para pelaku industri pariwisata.

\section{B. Langkah Penelitian.}

Dalam penelitian ini akan diselesaikan dengan mengikuti langakanh-langkah sesuai dengan gambar berikut:

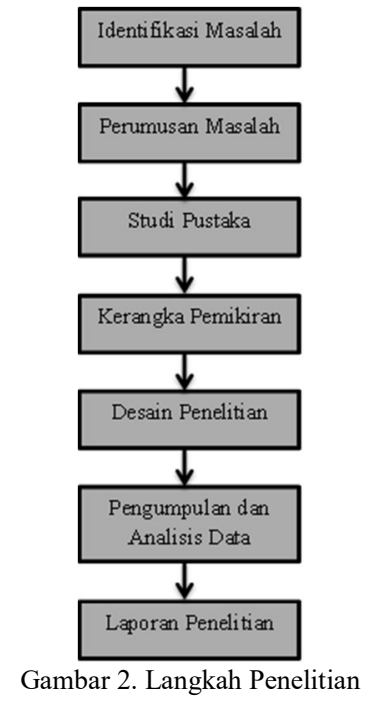

\section{Populasi dan Sample Penelitian}

Populasi yang akan dijadikan sebagai sumber data dalam penelitian ini adalah seluruh pengelola wisata bahari di 4 kecamatan lokasi penelitian. Berdasarkan data yang didapatkan bahwa populasi penelitian dapat diambil dari anggota asosiasi pengusaha wisata bahari kota Batam, pengelola seluruh objek wisata pantai dan bahari pelaku usaha, seluruh pelaku usaha yang ikut dalam industri wisata bahari yang ada di kota Batam. Peneliti memutusakan untuk menggunakan seluruh jumlah populasi sebagai sampel penelitian yakni 70 sampel penelitian.

\section{Rancangan Penelitian dan Hipotesis Penelitian}

Variabel yang digunakan dalam penelitian ini adalah variabel bebas (independent variable) dan variabel terikat (dependent variable). Variabel bebas (independent variable) yang digunakan berasal dari dimensi Implemenasi media sosial yakni komunikasi (communication and information delivery), dukungan proses bisnis (business support), berbagi pengetahuan (knowledge sharing), pembangunan hubungan atau jaringan (building business network). Kemudian variabel terikat yang digunakan yang diambil dari industri pariwisata adalah peningkatan kunjungan, kualitas objek wisata, popularitas objek wisata, peningkatan pendapatan secara ekonomi.

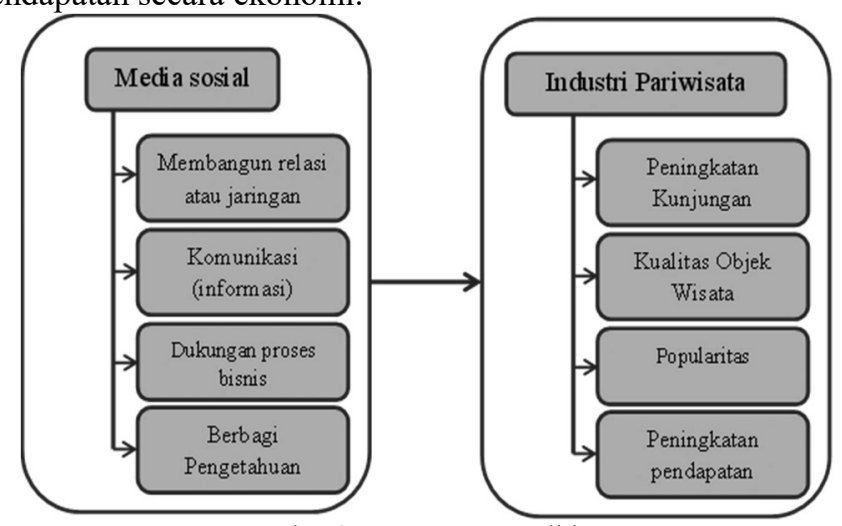

Gambar 3. Rancangan Penelitian 
Berdasarkan rancangan penelitian dan variable penelitian yang dibahas maka peneliti mengajukan Hipotesis yang penelitian sebagai berikut:

Ho: Implementasi media sosial tidak memberikan pengaruh terhadap pelaku industri pariwisata bahari di kota Batam

Ha: Implementasi media sosial memberikan pengaruh terhadap pelaku industri bahari di kota Batam

\section{E. Teknik Pengumpulan Data dan Pengolahan Data.}

Teknik pengumpulan data yang akan digunakan pada penelitian ini dengan menggunakan metode wawancara lansgung serta menggunakan alat pengumpul data dari pada responden yaitu dnegan dengan menggunakan kuesioner (questionnaire). Pertanyaan yang diajukan kepada responden adalah sesuai dengan variable penelitian yang digunakan dalam mengukur implementasi media sosial oleh pelaku wisata pada industri wisata di kota Batam.

Untuk melakukan analisa data dan pengolahan data penelitian yang telah dikumpulkan peneliti menggunakan analisa regresi dengan melakukan uji hipotesis melalui uji-t pada spss. Kemudian juga menggunakan analisa deskriptif untuk memberikan penjelasan terkait dengan implementasi platform media sosial pada industri wisata di kota Batam.

\section{Pembahasan}

\section{A. Hasil Penelitian}

Jumlah responden yang mengikuti penelitian ini adalah 70 responden. Namun sebanyak 16 responden tidak mengembalikan kuesioner sehingga jumlah kuesioner yang dikembalikan kepada peneliti adalah ebanyak 54 kuesioner. Dalam pengumpulan data peneliti menggunakan metode pengumpulan data kuesioner secara langsung atau menggunakan versi cetak dan juga menggunakan media elektronik (google form) untuk mengumpulkan data dari responden. Hasil penelitian ini ditampilkan dengan cara deskriptif untuk menjelaskan hasil pengolahan data yang dilakukan. Hasil penelitian yang didapatkan setelah melakukan langkah-langkah pengolahan data yakni sebagai berikut:

\section{1) Demografi Respondent \\ a) Jenis Wisata Bahari yang Dikelola}

Pada gambar dibawah terlihat bahwa jenis wisata yang banyak ditawarkan dan dilakukan oleh wisatawan adalah wisata pantai, diikuti oleh wisata snorkelling atau diving dan wisata fishing

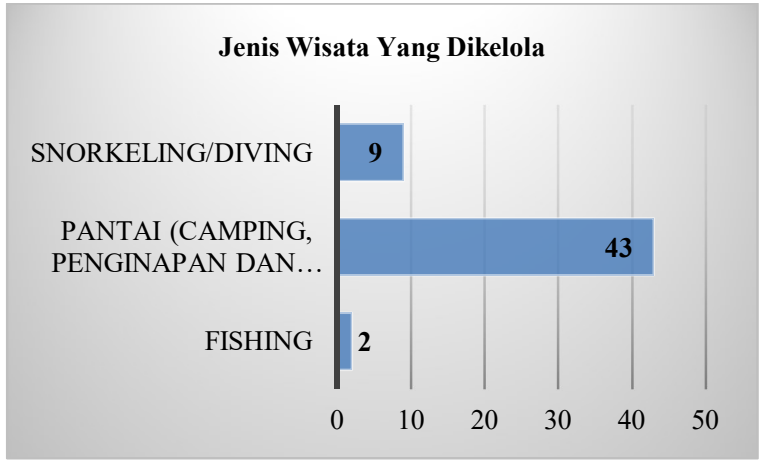

Gambar 4. Grafik jenis wisata bahari di kota Batam

Berdasarkan data diatas terlihat bahwa jenis wisata bahari yang dikelola di kota Batam adalah dominan pada wisata pantai (camping, penginapan dan atraksi wisata lainnya, kemudian bidanga wisata snorkelling/diving sebanyak 9 pengusaha dan bidang fishing (memancing sebanyak 2) sehingga total seluruhnya adalah 54.

\section{b) Platform Media Social yang Digunakan}

Pada gambar dibawah ini ditunjukan platform media sosial yang digunakan oleh pelaku industri wisata sebagai media untuk support bisnis. Dari seluruh data yang dikumpulkan maka pengusaha wisata $100 \%$ menggunakan akun facebook, kemudian platform Instagram digunakan oleh 53 orang, whatsapp grup digunakan oleh 27 orang, youtube 13 orang, Line sebanyak 6 orang dan linkedin sebanyak 3 orang. Total responden adalah 54 orang namun satu pengusaha memungkinkan menggunakan lebih dari satu platform media sosial.

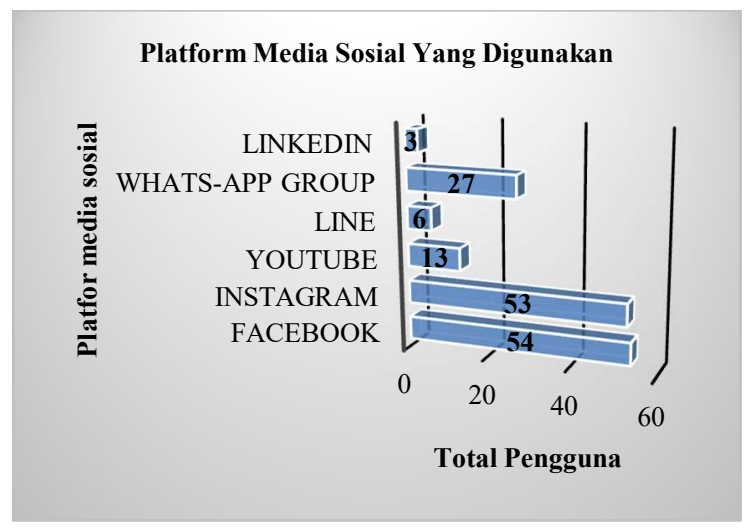

Gambar 5. Platform media sosial yang digunakan

c) Jenis Account yang Digunakan Pelaku Industri

Pelaku industri wisata tidak seluruhnya menggunakan akun yang ditujukan untuk kegiatan usaha atau bisnis. Berikut grafik penggunaan akun pada media sosial yang digunakan: 


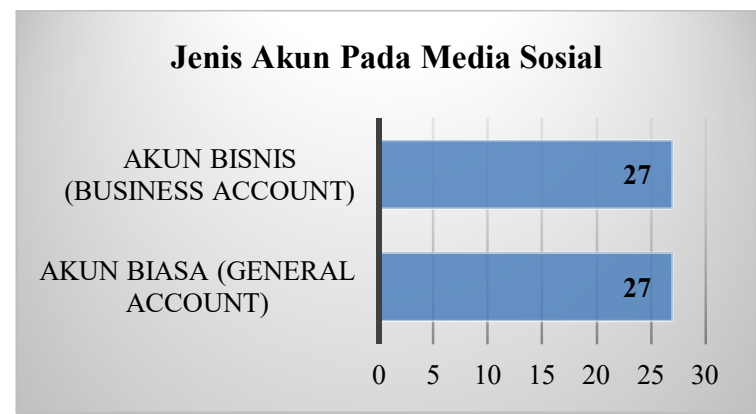

Gambar 6. Jenis akun media sosial yang digunakan

d) Jumlah Pengunjung yang Diterima Pelaku Industri

Pelaku industri wisata yang ada di Batam memiliki kapasitas pelayanan kepada pengunjung wisatawan dan jumlah permintaan yang ada juga berbeda-beda. Dibawah ini adalah gambaran jumlah permintaan yang ada pada setiap pelaku industri wisata bahari di kota Batam

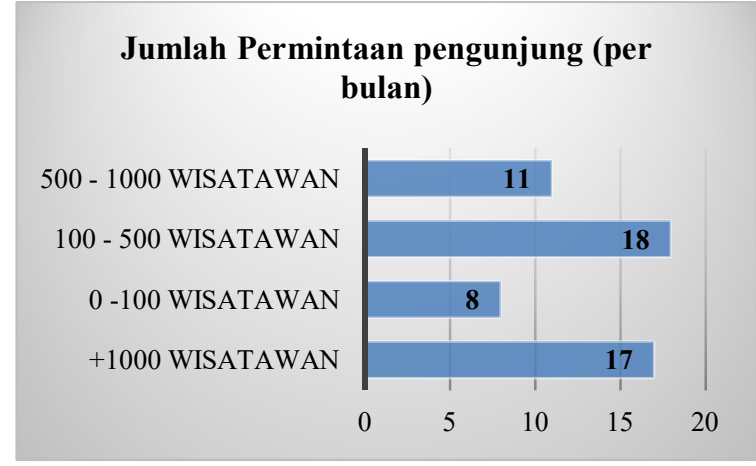

Gambar 7. Jumlah pengunjung yang dilayani oleh pelaku usaha industri wisata bahari.

e) Lokasi Objek atau Tujuan Wisata yang Dikelola

Lokasi objek wisata di kota Batam juga tersebar hamper di seluruh pesisir kota Batam yaitu seperti terlihat dalam grafik berikut:

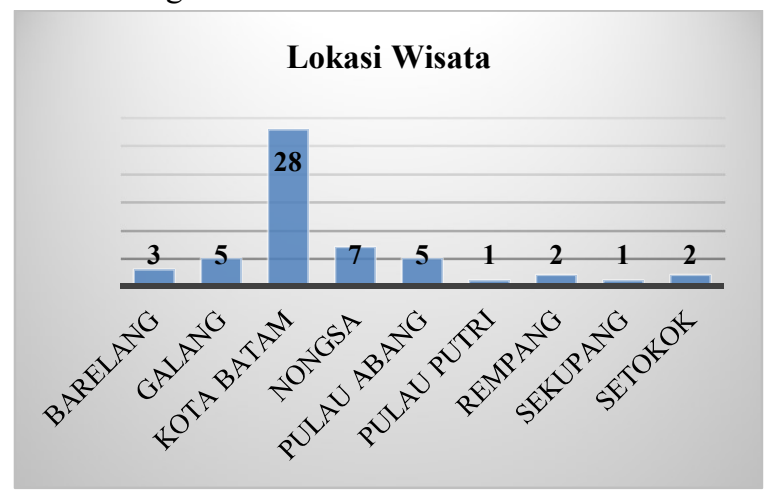

Gambar 8. Sebaran Lokasi wisata bahari di Kota Batam.

\section{f) Peran Pelaku Industri Wisata Bahari Di Kota Batam}

Peran yang dilaksanakan oleh pelaku industri wisata bahari di kota Batam dapat dilihat melalui gambar berikut ini:

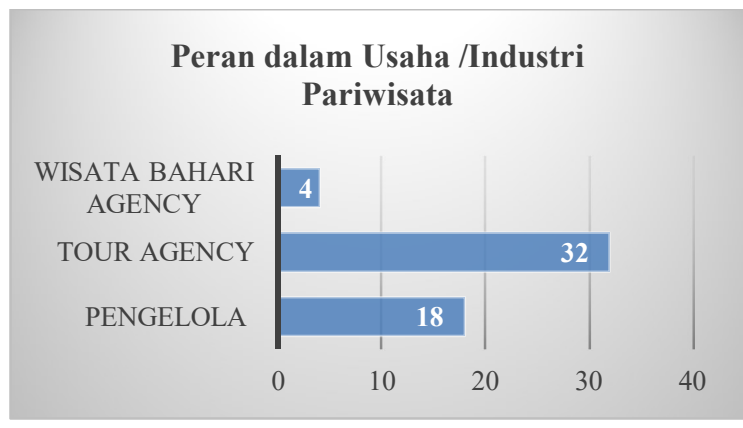

Gambar 9. Peran pelaku industri wisata bahari di kota Batam

\section{2) Validitas dan Reliabilitas}

Data penelitian yang telah dikumpulkan menggunakan quesionaire menggunakan angket dan gorm elektronik diuji validitas dan reliabilitas sehingga data yang terkumpul dinyatakan valid dan handal dalam mewakili tujuan dan esensi penelitian. Berikut merupakan hasil uji validitas dan reliabilitas data kuesioner yang telah diuji:

a) Validitas.

Hasil uji validitas yang didapatkan adalah sebagai berikut:

TABEL 1

HASIL UJI VALIDITAS ITEM KUESIONER

\begin{tabular}{|l|l|}
\hline \multicolumn{1}{|c|}{ Item Pertanyaan } & $\begin{array}{l}\text { Nilai } \\
\text { Validita } \\
\text { s } \\
\text { (person } \\
\text { correlati } \\
\text { on) }\end{array}$ \\
\hline $\begin{array}{l}\text { Membangun jaringan/kelompok untuk } \\
\text { calon wisatawan/turis/pengunjung } \\
\text { wisata }\end{array}$ & $.574^{* *}$ \\
\hline $\begin{array}{l}\text { Membangun komunikasi dengan calon } \\
\text { wisatawan/turis/pengunjung wisata. }\end{array}$ & $.402^{* *}$ \\
\hline $\begin{array}{l}\text { Sebagai alat atau platform utama yang } \\
\text { mendukung proses bisnis }\end{array}$ & $.627^{* *}$ \\
\hline $\begin{array}{l}\text { Media berbagi pengatahuan, tips dan } \\
\text { cara-cara unik (trick) kepada calon } \\
\text { wisatawan/turis/pengunjung }\end{array}$ & $.749^{* *}$ \\
\hline $\begin{array}{l}\text { Meningkatkan tingkat kunjungan atau } \\
\text { penjualan paket wisata }\end{array}$ & $.815^{* *}$ \\
\hline $\begin{array}{l}\text { Meningkatkan kualitas layanan yang } \\
\text { disediakan kepada wisatawan }\end{array}$ & $.435^{* *}$ \\
\hline $\begin{array}{l}\text { Meningkatkan popularitas objek } \\
\text { wisata }\end{array}$ & $.749^{* *}$ \\
\hline $\begin{array}{l}\text { Meningkatan pendapatan secara } \\
\text { ekonomi. }\end{array}$ & $.807^{* *}$ \\
\hline
\end{tabular}

b) Reliabilitas

Hasil uji reliabilitas yang didapatkan adalah sebagai berikut. 
TABEL II.

HASIL UJI RELIABILITAS ITEM KUESIONER

\begin{tabular}{|r|r|}
\hline $\begin{array}{c}\text { Cronbach's } \\
\text { Alpha }\end{array}$ & N of Items \\
\hline .791 & 8 \\
\hline
\end{tabular}

Hasil uji diatas menunjukan bahwa nilai cronbachs alpha yaitu 0.791 dan ilai tersebut lebih besar dari 0,6 yang merupakan batas akhir reliabilitas minimum pada uji reliabilitas

3) Uji Regresi

Untuk menguji hipotesis yang telah diajukan sebelumnya maka dilakukan pengujian data yang telah ada menggunakan Uji regresi. Regresi yang digunakan yaitu regresi linier sederhana. Berikut merupakan hasil uji regresi yang dihasilkan:

TABEL III

MODEL SUMMARY

\begin{tabular}{|l|c|r|r|r|}
\hline Model & $\mathrm{R}$ & $\begin{array}{c}\mathrm{R} \\
\text { Square }\end{array}$ & $\begin{array}{c}\text { Adjusted } \\
\text { R Square }\end{array}$ & $\begin{array}{c}\text { Std. Error of } \\
\text { the Estimate }\end{array}$ \\
\hline 1 & $.724^{\mathrm{a}}$ & .524 & .515 & 1.04747 \\
\hline
\end{tabular}

Pada tabel diatas Nilai $\mathrm{R}$ adalah 0,724 dimana nilai tersebut menunjukan variabel media sosial dengan industri wisata bahari memiliki hubungan yang kuat. Nilai $\mathrm{R}$ square adalah 0,524 yang diartikan bahwa 52,5\% media sosial memiliki pengaruh terhadap variabel industri pariwisata bahari.

TABEL IV

ANOVA TEST

\begin{tabular}{|l|l|r|r|r|c|c|}
\hline \multicolumn{2}{|l|}{ Model } & $\begin{array}{c}\text { Sum of } \\
\text { Squares }\end{array}$ & df & $\begin{array}{c}\text { Mean } \\
\text { Square }\end{array}$ & F & Sig. \\
\hline \multirow{3}{*}{1} & Regression & 62.872 & 1 & 62.872 & 57.302 & $.000^{\mathrm{b}}$ \\
\cline { 2 - 7 } & Residual & 57.054 & 52 & 1.097 & & \\
\cline { 2 - 8 } & Total & 119.926 & 53 & & & \\
\hline
\end{tabular}

Pada tabel diatas Nilai signifikansi Sig. adalah 0,000 dimana nilai tersebut adalah lebih kecil dari 0.05 dan hal tersebut menunjukan bahwa model regresi yang didapatkan adalah linier.

TABEL V

COEFFICIENTS TEST

\begin{tabular}{|c|c|c|c|c|c|c|}
\hline \multirow{2}{*}{\multicolumn{2}{|c|}{ Model }} & \multicolumn{2}{|c|}{$\begin{array}{c}\text { Unstandardized } \\
\text { Coefficients }\end{array}$} & $\begin{array}{l}\text { Standardized } \\
\text { Coefficients }\end{array}$ & \multirow[t]{2}{*}{$\mathrm{t}$} & \multirow[t]{2}{*}{ Sig. } \\
\hline & & $\bar{B}$ & $\begin{array}{l}\text { Std. } \\
\text { Error }\end{array}$ & Beta & & \\
\hline \multirow[t]{2}{*}{1} & (Constant) & 3.011 & 1.990 & & 1.513 & .136 \\
\hline & $\mathrm{x} 1$ & .830 & .110 & .724 & 7.570 & .000 \\
\hline
\end{tabular}

Pada tabel diatas Nilai konstan unstandardized coeficients adalah 3.011, Kemudian nilai koefisien regresi adalah 0.830 . sehingga persamaan regresi linier sederhana yang dihasilkan dari hasil uji diatas adalah:

$\mathrm{Y}=\mathrm{a}+\mathrm{bX}$
$\mathrm{Y}=3.011+0.830 \mathrm{X}$

\section{4) Uji Hipotesis}

Untuk melihat apakah hipotesis yang diajukan pada penelitian ini maka penulis menggunakan hasil dari uji koefisien yang telah didapatkan menggunakan table $\mathrm{V}$ yaitu nilai Siginifikansi korelasi yaitu 0.000 . Hasil ini berarti bahwa nilai signifikansi tersebut lebih kecil 0,05 (0.000< 0.05 ) dan hasil uji hipotesis yang diambil berdasarkan hasil tersebut adalah sebagai berikut:

Ho: Implementasi media sosial tidak memberikan pengaruh terhadap pelaku industri pariwisata bahari di kota Batam, Hipotesis Ditolak

Ha: Implementasi media sosial memberikan pengaruh terhadap pelaku industri bahari di kota Batam, Hipotesis Diterima.

\section{B. Pembahasan}

Penelitian in dilakukan di kota Batam yang melibatkan pengelola industri pariwisata bahari. Responden yang ikut terlibat adalah pengelola tour agency, pemilik atau pengelola pantai, travel agency dan komunitas terkait yang ikut dalam industri wisata bahari. Objek wisata yang ada dikota Batam yang ikut dalam penelitian ini tersebar dalam 4 kecamatan yaitu kecamatan Galang, Kecamatan Bulang, Kecamatan Nongsa dan Kecamatan Sekupang.

Terdapat beberapa platform media sosial yang digunakan oleh pelaku industri wisata di kota Batam yaitu Facebook, Instagram, Youtube, Whatsapp group, Line, Twitter dan Linkedin. Berdasarkan data penelitian yang terkumpul ditemukan bahwa facebook merupakan platform media sosial yang digunakan oleh seluruh responden hal ini berarti facebook merupakan platform yang paling banyak digunakan dibandingkan dengan platform lain, platform Instagram merupakan platform terbanyak kedua setelah facebook yang digunakan oleh pelaku industry wisata di kota Batam dan yang paling sedikit adalah platform jaringan bisnis linkedin. Melihat intensitas penggunaan media sosial oleh pelaku industry maka jenis akun yang digunakan oleh pelaku industri wisata bahari tidak seluruhnya menggunakan akun bisnis atau akun yang memiliki fitur bisnis yang sangat banyak memiliki fitur-fitur tambahan dalam meningkatkan bisnis namun pengusaha juga masih banyak yang hanya mengandalkan atau menggunakan akun biasa.

Berdasarkan hasil uji data pada Tabel V didapatkan bahwa nilai $\mathrm{B}$ adalah 0.830 , nilai t hitung pada coefficients test adalah 7,570 dan nilai signifikansi adalah 0.000 . Menggunakan ketentuan yang ada bahawa nilai siginifikansi lebih kecil dari 0,05 maka disimpulkan ada pengaruh pada variable yang diuji. Sehingga berdasarkan hasil uji data 
tersebut dapat diambil persamaan Hasil uji regresi yang dihasilkan adalah sebagai berikut

$\mathrm{Y}=3.011+0.830 \mathrm{X}$.

Berdasarkan ketentuan pada regresi liner sederhana diatas diartikan bahwa hasil uji Hipotesis yang dihasilkan dalam penelitian ini adalah adanya pengaruh variabel independenet yakni Implementasi media sosial terhadap variabel (dependent) pelaku industri pariwisata bahari di kota Batam. Hipotesis ini juga memberikan kesimpulan bahwa ada pengaruh yang kuat antara implementasi media sosial dengan industri pariwisata bahari di kota Batam. Hal ini sesuai dengan penelitian yang dilakukan oleh Zeng [7], [6], [21], [22], [23].

\section{KESIMPULAN}

Seluruh pelaku industri bahari telah menggunaan platform media sosial dlam menunjang kegiatan proses bisnis yang mereka lakukan. Platform media sosial yang paling banyak digunakan oleh pelaku industri adalah Facebook dan Instagram dimana facebook digunakan oleh seluruh pelaku industri wisata di kota Batam. Berdasarkan hasil uji data penelitian disimpulkan bahwa terdapat pengruh/kegunaan yang didapatkan oleh pelaku industri wisata bahari di kota Batam dalam meningkatkan bisnis, keuntungan perusahaan dan juga meningkatkan kunjungan wisatawan melalui agensi perjalanan yang disediakan ataupun meningkatnya kunjungan langsung ke objek wisata yang dikelola. Terdapat keuntungan yang didapatkan seluruh pihak dalam implementasi media sosial terhadap pelaku industri wisata bahari di kota Batam

Penelitian ini juga mengungkapkan bahwa masih adanya pengaruh dari variabel lain yang dapat digunakan untuk meningkatkan industri pariwisata bahari di kota Batam yang dapat digunakan oleh pelaku industri ini. Kota Batam yang memiliki sebaran objek wisata bahari yang luas sangat mendukung hal tersebut. Penggunaan akun bisnis pada platform media sosial seharusnya lebih ditingkatan menjadi akun bisnis agar seluruh fitur bisnis yang disediakan dapat membantu para pelaku usaha tersebut.

\section{UCAPAN TERIMA KASIH}

Peneliti berterima kasih kepada seluruh pihak yang ikut dalam membantu menyeelsaikan penelitian ini termasuk Pemerintah Republik Indonesia melalui DIKTI, LPPM dan PJM universitas putera Batam dan seluruh responden penelitian yang tidak dapat disebutkan seluruhnya. Kami tim peneliti mengucapkan Terima Kasih.

\section{DAFTAR PUSTAKA}

[1] L. A. Divinagracia, M. R. G. Divinagracia, and D. G. Divinagracia, "Digital Media-Induced Tourism: The Case of Nature-based Tourism (NBT) at East Java, Indonesia," Procedia - Soc. Behav. Sci., vol. 57, pp. 85-94, 2012.

[2] W. T. \& T. C. WTTC, "Travel \& Tourism: economic impact 2016 world," no. 2016, p. 20, 2016.

[3] G. Gumilar, "Pemanfaatan Instagram Sebagai Sarana Promosi Oleh Pengelola Industri Kreatif Fashion Di Kota Bandung," JIPSi, vol. V, no. 2, 2015.

[4] S. Hays, S. J. Page, and D. Buhalis, "Social media as a destination marketing tool: its use by national tourism organisations," Curr. Issues Tour., vol. 16, no. 3, pp. 211-239, 2013.

[5] N. E. S. Derani and P. Naidu, "The Impact of Utilizing Social Media as a Communication Platform during a Crisis within the Oil Industry," Procedia Econ. Financ., vol. 35, no. October 2015, pp. 650-658, 2016.

[6] R. Zivkovic, J. Gajic, and I. Brdar, "The Impact of Social Media on Tourism," Proc. 1st Int. Sci. Conf. Sint. 2014, pp. 758-761, 2014.

[7] B. Zeng, "Social Media in Tourism," J. Tour. Hosp., vol. 02, no. 02, pp. 1-2, 2013.

[8] S. Kemp, "Digital In 2017 : Global Review," 2017. [Online]. Available:

https://wearesocial.com/sg/blog/2017/01/digital-in2017-global-overview. [Accessed: 02-Jun-2017].

[9] C. A. Elena, "Social Media - A Strategy in Developing Customer Relationship Management," Procedia Econ. Financ., vol. 39, no. November 2015, pp. 785-790, 2016.

[10] W. T.\& T. C. WTTC, "TRAVEL \& TOURISM GLOBAL ECONOMIC IMPACT \& ISSUES 2017,” 2017.

[11] Bps Kepulauan Riau, "Statistik Pengunjung Wisatawan Mancanegara Kepulauan Riau," Kepulauan Riau, 2017.

[12] Bappeda-Kepri, "Potensi Daerah Sektor Pariwisata KEPRI,” 2017. [Online]. Available:

http://bappeda.kepriprov.go.id/index.php/datainformasi/potensi-daerah/47-potensi-daerah/207sektor-pariwisata. [Accessed: 01-Jan-2017].

[13] H. Delerue, A. M. Kaplan, and M. Haenlein, "Social media: Back to the roots and back to the future," $J$. Syst. Inf. Technol., 2012.

[14] T. Ahlqvist, A. Bäck, S. Heinonen, and M. Halonen, "Road-mapping the societal transformation potential of social media," foresight, 2010.

[15] S. Toivonen, Web on the Move. 2007.

[16] A. M. Kaplan and M. Haenlein, "The challenges and opportunities of Social Media,” Bus. Horiz., 2010.

[17] A. Kiralova and A. Pavliceka, "Development of Social Media Strategies in Tourism Destination," Procedia - Soc. Behav. Sci., vol. 175, pp. 358-366, 2014.

[18] S. Kurniali, "Pengaruh Internet Marketing Terhadap Brand Dan Kinerja Pada Universitas Swasta Di Jakarta Barat," Juni, vol. 3, no. 1, p. 432443, 2012. Z. Altinay, T. Saner, N. M. Bahcelerli, and F. 
Altinay, "The Role of Social Media Tools: Accessible Tourism for Disabled Citizens.: Sistema de descoberta para FCCN," vol. 19, pp. 89-99, 2016.

[20] K. Pariwisata and Indonesia, Peraturan Pemerintah Indonesia Nomor 50 Tahun 2011. Indonesia, Indonesia, 2011.

[21] M. Sixt, "Social Media in the Tourism Industry: How Social Media and The Self Congruity Theory affect Destination Choice," 2013.

[22] T. Siswanto, "Optimalisasi Sosial Media Sebagai
Media Pemasaran Usaha Kecil Menengah,” Liquidity, vol. 2, no. 1, pp. 80-86, 2013.

[23] I. Bizirgianni and P. Dionysopoulou, "The Influence of Tourist Trends of Youth Tourism through Social Media (SM) \& information and Communication Technologies (ICTs)," Procedia - Soc. Behav. Sci., vol. 73, pp. 652-660, 2013. 